\title{
Distribution of the Fasting Lipid Levels and Validation of the Reference Interval in Korean Adolescents
}

\author{
Seyoung Kwon, Youngak Na
}

Department of Biomedical Laboratory Science, Daegu Health College, Daegu, Korea

\section{우리나라 소아청소년의 공복 혈중 지질 농도의 분포 및 참고범위의 타당성 검증}

권세영, 나영악

대구보건대학교 임상병리과

\begin{abstract}
With the growing prevalence of dyslipidemia in adolescents, its early detection and management is becoming increasingly important. This study overviewed the fasting lipid concentration distribution of adolescents according to the sex and age, and reviewed the percentile of its reference interval. This study targeted 2,713 adolescents aged between 10 and 19 (1,436 boys, 1,275 girls) based on the data from 2013 to 2016, Korean Health and Nutrition Examination Survey. The mean fasting lipid concentration of total cholesterol, LDL cholesterol, HDL cholesterol, non-HDL cholesterol, and triglyceride of girls was higher than those of boys. Although the $95^{\text {th }}$ percentile of the cholesterol value was $200 \mathrm{mg} / \mathrm{dL}$ in boys, which was equivalent to the diagnosis criterion, the mean value of girls was $208 \mathrm{mg} / \mathrm{dL}$, staying between the $90^{\text {th }}$ and $95^{\text {th }}$ percentiles. The $95^{\text {th }}$ percentiles of the LDL cholesterol, non-HDL cholesterol, and triglyceride value were 123, 148, and $147 \mathrm{mg} / \mathrm{dL}$ in boys, respectively, and 131,149, and $139 \mathrm{mg} / \mathrm{dL}$ in girls, respectively. Most of the criteria of dyslipidemia were at the proper level, within the $90^{\text {th }}$ and $95^{\text {th }}$ percentile. While the criteria of LDL cholesterol $(130 \mathrm{mg} / \mathrm{dL})$ was higher in boys, the triglycerides was higher in girls. In conclusion, criteria more suitable to Korean adolescents will need to be established with further studies.
\end{abstract}

Key words: Criteria of dyslipidemia, Fasting lipid levels, Reference interval

This is an Open Access article distributed under the terms of the Creative Commons Attribution Non-Commercial License (http://creativecommons.org/licenses/by-nc/4.0) which permits unrestricted non-commercial use, distribution, and reproduction in any medium, provided the original work is properly cited.

Copyright ( 2018 The Korean Society for Clinical Laboratory Science. All rights reserved.
Corresponding author: Seyoung Kwon Department of Biomedical Laboratory Science, Daegu Health College, 15 Yeongsong-ro, Buk-gu, Daegu 41453, Korea

Tel: 82-53-320-1362

Fax: 82-53-320-1450

E-mail: sykwon@dhc.ac.kr

Received: August 3, 2018

Revised: August 21, 2018

Accepted: August 30, 2018

\section{서 론}

심혈관질환으로 인한 사망률은 우리나라 뿐 아니라 전세계 적으로 여전히 높다[1, 2]. 그 위험인자로 비만, 고혈압, 흡연, 이 상지질혈증 등이 알려져 있으며, 특히 이상지질혈증을 포함한 여러가지 위험요인들이 소아청소년기에서부터 시작된다는 보 고와 함께 그 중요성이 꾸준히 강조되고 있다[3-6]. 소아청소년 기의 이상지질혈증 유병율이 증가함에 따라[7] 이에 대한 조기
발견과 관리에 대한 중요성이 커지고 있으나, 혈중 지질치는 소 아청소년기의 성장과 발달에 따라 연령과 성별에 따라 혈중 농 도가 변화하므로 $[8,9]$ 성인과 다른 진단 기준이 필요함에도 불 구하고, 여전히 진단에 대한 기준은 다양하게 제시되고 있다. 소 아청소년기의 지질단백질 농도에 대한 연구가 지속되어 왔으나 $[10,11]$, 여러 연구에서 심혈관질환, 대사증후군 등 다양한 위 험 질환에 따라 기준이 다양하게 제시되었고 국내 소아청소년 을 대상으로 한 기준범위와 관련한 대규모 연구는 많지 않은 실 
정이다.

이에 본 연구에서는 국가단위의 대규모 조사자료를 근거로 10 19세 소아청소년의 성별과 연령에 따른 공복 혈청 지질 농 도의 분포를 살펴보고, 참고 범위 설정을 위한 백분위수 값을 검 토하여 이상지질혈증 진단기준과 비교해 봄으로써 참고범위의 타당성을 검증해보고자 하였다.

\section{재료 및 방법}

\section{1. 연구대상}

2013년부터 2016년까지 총 4년에 걸친 국민건강영양조사 에서 10 세 이상 20 세 미만 연령의 소아청소년 총 3,522 명(남아 1,851 명, 여아 1,671 명) 중 혈중 지질 측정치 누락자와 공복 8 시 간 미충족자, Friedwald 공식 적용 제외 범위인 중성지방 수치 가 $400 \mathrm{mg} / \mathrm{dL}$ 이상인 자, 이상지질혈증 치료 중 인자를 제외한 총 2,711 명(남자 1,436 명, 여자 1,275 명)의 데이터를 대상으로 하였다. 본 연구는 동 기간 동안 수행된 조사자료를 대상으로 분 석을 시행하였다(승인번호: 2013-07CON-03-4C, 2013-12EXP03-5C).

\section{2. 연구 방법}

혈액 검사 결과는 8시간 이상의 공복 상태를 유지한 대상자 들의 자료를 이용하였다. 측정 시약 및 방법은 총콜레스테롤의 경우, Pureauto SCHO-N, HDL (high-density lipoprotein) 콜레스테롤은 Cholestest N HDL, LDL (low-density lipoprotein) 콜레스테롤은 Cholestest LDL, 중성지방(triglyceride, TG)은 Pureauto S TG-N (Daiichi Pure Chemicals Corporation, Tokyo, Japan)을 사용하여 효소법으로 측정하 였고, 측정 장비는 Hitachi 7600 및 7600-210 (Hitachi high-technologies Co., Tokyo, Japan) 자동화학 분석기를 사 용하였다. HDL 콜레스테롤 측정치는 가장 최근에 수정 보완된 전환식 적용자료 $(2013$ 2014년의 경우 $\mathrm{HDL}$ 원자료 $\times 0.952)+$ 1.096, 2015 2016년의 경우 HDL 원자료×1.010)-3.172) 를 사용하고 LDL 콜레스테롤 측정치는 Friedwald 공식을 이용 한 LDL 콜레스테롤의 계산법(calculated LDL cholesterol= total cholesterol-HDL cholesterol-triglyceride/5)을 공통 적으로 적용하여 산출된 값을 이용하였다. Non-HDL 콜레스테 롤은 총콜레스테롤 수치와 $\mathrm{HDL}$ 콜레스테롤 수치의 차로 산출 된 값을 적용하였다.

\section{3. 통계 분석}

본 연구 대상자의 성별과 연령에 따른 공복 혈중 지질 농도의 분포를 살펴보기 위해 성별·연령별 총콜레스테롤, LDL 콜레스 테롤, $\mathrm{HDL}$ 콜레스테롤, non-HDL 콜레스테롤, 중성지방의 평 균, 중위수, 표준편차(SD), 표준오차(SE)에 대한 기술통계를 제 시하였으며, 각각 검진 가중치가 반영된 값을 나타내었다. 참고 범위 설정을 위한 백분위수 산정 시 사분위수를 바탕으로 box-plot을 이용하여 whisker에 해당하는 상한치와 하한치를 정하여 이보다 바깥쪽에 존재하는 이상값을 제외한 후, 연령별 각 지질 지표의 백분위수를 2.5 백분위수(2.5th percentiles)에 서 97.5백분위수(97.5th percentiles)까지 구간별로 나누어 구 하였다. 자료에 대한 통계분석은 IBM SPSS Statistics 23.0 (IBM, NY, USA)을 사용하였다.

\section{결 과}

\section{1. 공복 총콜레스테롤 평균 농도}

성별에 따른 공복 혈중 농도의 비교에서 남아 대상자 1,424 명의 평균 농도는 $156.1 \mathrm{mg} / \mathrm{dL}$, 여아 대상자 1,261 명의 농도는 $164.8 \mathrm{mg} / \mathrm{dL}$ 로 여아의 평균치가 남아보다 더 높았다. 연령에 따른 농도 비교에서 10세 남아의 평균은 $171.1 \mathrm{mg} / \mathrm{dL}$, 여아의 평균은 $171.0 \mathrm{mg} / \mathrm{dL}$ 으로 평균 농도는 남녀 모두 10세에서 가 장 높았다. 2.5 백분위수와 97.5 백분위수에 해당하는 범위는 남 아 $110 \sim 209 \mathrm{mg} / \mathrm{dL}$, 여아 $120 \sim 218 \mathrm{mg} / \mathrm{dL}$ 였고, 95백분위수 에 해당하는 농도는 남아 $200 \mathrm{mg} / \mathrm{dL}$, 여아 $208 \mathrm{mg} / \mathrm{dL}$ 였다 (Tables 1, 2) (Figure 1A, 1B).

\section{2. 공복 $\mathrm{LDL}$ 콜레스테롤 평균 농도}

$\mathrm{LDL}$ 콜레스테롤의 경우 남아의 평균 농도는 $87.6 \mathrm{mg} / \mathrm{dL}$, 여 아의 평균 농도는 $93.8 \mathrm{mg} / \mathrm{dL}$ 로 여아의 평균치가 남아보다 더 높았다. 연령에 따른 농도 비교에서 10세 남아의 평균은 96.3 $\mathrm{mg} / \mathrm{dL}$, 여아의 평균은 $98.7 \mathrm{mg} / \mathrm{dL}$ 로 평균 농도는 남녀 모두 10 세에서 가장 높고 $13 \sim 15$ 세까지 감소하다가 다시 증가하는 경향을 보였다. 2.5 백분위수와 97.5 백분위수에 해당하는 범위 는 남아 50 130 mg/dL, 여아 54 135 mg/dL였고, 95백분위 수에 해당하는 농도는 남아 $123 \mathrm{mg} / \mathrm{dL}$, 여아 $131 \mathrm{mg} / \mathrm{dL}$ 였다 (Tables 1, 2) (Figure 1C, 1D).

\section{3. 공복 $\mathrm{HDL}$ 콜레스테롤 평균 농도}

$\mathrm{HDL}$ 콜레스테롤의 경우 남아의 평균 농도는 $50.4 \mathrm{mg} / \mathrm{dL}$, 여 
Table 1. Distribution of serum lipid levels according to the percentile based on age groups in boys

\begin{tabular}{|c|c|c|c|c|c|c|c|c|c|c|c|c|c|c|}
\hline \multirow{2}{*}{ Age } & \multirow{2}{*}{$\begin{array}{l}\text { Unwei- } \\
\text { ghted N }\end{array}$} & \multirow{2}{*}{ Median } & \multirow{2}{*}{ Mean } & \multirow{2}{*}{ SD } & \multirow{2}{*}{ SE } & \multicolumn{9}{|c|}{ Percentile } \\
\hline & & & & & & 2.5 & 5 & 10 & 25 & 50 & 75 & 90 & 95 & 97.5 \\
\hline \multicolumn{15}{|c|}{ Total cholesterol(mg/dL) } \\
\hline 10 & 134 & 172 & 171.1 & 22.9 & 2.1 & 131 & 135 & 138 & 156 & 172 & 184 & 203 & 212 & 220 \\
\hline 11 & 163 & 163 & 163.8 & 23.1 & 1.9 & 116 & 122 & 134 & 147 & 163 & 179 & 194 & 204 & 218 \\
\hline 12 & 133 & 152 & 156.5 & 23.5 & 2.2 & 120 & 127 & 132 & 139 & 152 & 171 & 191 & 201 & 205 \\
\hline 13 & 171 & 147 & 148.6 & 21.8 & 1.8 & 109 & 117 & 124 & 135 & 147 & 161 & 178 & 187 & 199 \\
\hline 14 & 149 & 151 & 151.9 & 24.2 & 2.1 & 106 & 115 & 122 & 135 & 151 & 168 & 188 & 194 & 202 \\
\hline 15 & 154 & 149 & 150.4 & 27.0 & 2.3 & 101 & 110 & 119 & 132 & 149 & 169 & 183 & 205 & 213 \\
\hline 16 & 125 & 152 & 152.5 & 22.3 & 2.1 & 111 & 116 & 125 & 135 & 152 & 169 & 182 & 189 & 198 \\
\hline 17 & 138 & 148 & 150.1 & 23.9 & 2.1 & 111 & 115 & 121 & 132 & 148 & 166 & 183 & 193 & 207 \\
\hline 18 & 130 & 158 & 155.8 & 25.0 & 2.5 & 105 & 117 & 121 & 138 & 158 & 172 & 188 & 199 & 205 \\
\hline 19 & 127 & 164 & 165.6 & 24.6 & 2.4 & 116 & 122 & 132 & 151 & 164 & 185 & 197 & 210 & 218 \\
\hline total & 1,424 & 155 & 156.1 & 25.0 & 0.7 & 110 & 117 & 124 & 138 & 155 & 173 & 189 & 200 & 209 \\
\hline \multicolumn{15}{|c|}{ LDL cholesterol (mg/dL) } \\
\hline 10 & 131 & 99.1 & 96.3 & 19.9 & 1.9 & 61 & 64 & 69 & 81 & 99 & 109 & 123 & 130 & 135 \\
\hline 11 & 162 & 92.2 & 93.6 & 20.4 & 1.7 & 56 & 63 & 71 & 80 & 92 & 109 & 122 & 129 & 136 \\
\hline 12 & 132 & 83.2 & 86.9 & 20.4 & 2.0 & 52 & 58 & 62 & 73 & 83 & 100 & 116 & 127 & 133 \\
\hline 13 & 171 & 80.6 & 81.5 & 18.6 & 1.5 & 42 & 54 & 61 & 68 & 81 & 94 & 103 & 114 & 123 \\
\hline 14 & 148 & 84.1 & 85.2 & 20.1 & 1.8 & 49 & 51 & 62 & 69 & 84 & 97 & 112 & 119 & 122 \\
\hline 15 & 153 & 83.3 & 83.5 & 22.5 & 1.9 & 46 & 50 & 54 & 66 & 83 & 96 & 114 & 126 & 128 \\
\hline 16 & 123 & 85.3 & 85.8 & 19.1 & 1.9 & 46 & 54 & 61 & 73 & 85 & 99 & 112 & 119 & 124 \\
\hline 17 & 137 & 83.0 & 84.7 & 20.0 & 1.9 & 47 & 55 & 60 & 72 & 83 & 98 & 107 & 122 & 128 \\
\hline 18 & 130 & 88.0 & 88.2 & 21.6 & 2.1 & 50 & 52 & 61 & 72 & 88 & 105 & 117 & 123 & 133 \\
\hline 19 & 125 & 92.0 & 93.5 & 21.0 & 2.1 & 53 & 57 & 67 & 79 & 92 & 109 & 121 & 131 & 142 \\
\hline total & 1,412 & 86.7 & 87.6 & 21.0 & 0.6 & 50 & 54 & 61 & 73 & 87 & 101 & 117 & 123 & 130 \\
\hline \multicolumn{15}{|c|}{ HDL cholesterol (mg/dL) } \\
\hline 10 & 127 & 55.4 & 55.7 & 8.8 & 0.9 & 37 & 42 & 44 & 50 & 55 & 63 & 67 & 70 & 74 \\
\hline 11 & 157 & 52.4 & 52.9 & 9.8 & 0.9 & 34 & 36 & 41 & 46 & 52 & 60 & 65 & 72 & 75 \\
\hline 12 & 131 & 51.6 & 52.5 & 10.1 & 1.0 & 35 & 37 & 40 & 45 & 52 & 59 & 66 & 73 & 74 \\
\hline 13 & 170 & 49.4 & 50.5 & 9.6 & 0.8 & 34 & 36 & 38 & 44 & 49 & 57 & 64 & 68 & 72 \\
\hline 14 & 150 & 47.7 & 49.3 & 9.0 & 0.7 & 34 & 35 & 38 & 43 & 48 & 55 & 62 & 69 & 70 \\
\hline 15 & 155 & 47.3 & 48.3 & 8.5 & 0.7 & 31 & 34 & 39 & 42 & 47 & 54 & 60 & 62 & 65 \\
\hline 16 & 125 & 46.8 & 48.2 & 8.8 & 0.8 & 35 & 36 & 38 & 41 & 47 & 53 & 59 & 67 & 68 \\
\hline 17 & 139 & 48.7 & 48.4 & 7.8 & 0.7 & 33 & 37 & 38 & 42 & 49 & 52 & 58 & 63 & 66 \\
\hline 18 & 133 & 49.7 & 50.0 & 8.9 & 0.8 & 34 & 37 & 39 & 43 & 50 & 56 & 61 & 64 & 70 \\
\hline 19 & 129 & 50.6 & 54.5 & 9.2 & 0.8 & 34 & 36 & 40 & 44 & 51 & 57 & 63 & 69 & 74 \\
\hline total & 1,416 & 49.7 & 50.4 & 9.3 & 0.3 & 34 & 36 & 39 & 43 & 50 & 56 & 63 & 67 & 71 \\
\hline \multicolumn{15}{|c|}{ Non-HDL cholesterol (mg/dL) } \\
\hline 10 & 133 & 113.7 & 113.4 & 22.0 & 2.0 & 72 & 79 & 83 & 99 & 114 & 126 & 145 & 154 & 157 \\
\hline 11 & 163 & 106.7 & 109.6 & 22.7 & 1.9 & 70 & 75 & 83 & 94 & 107 & 125 & 141 & 152 & 166 \\
\hline 12 & 134 & 99.7 & 102.9 & 22.9 & 2.1 & 63 & 72 & 77 & 86 & 100 & 118 & 136 & 146 & 149 \\
\hline 13 & 170 & 96.3 & 97.7 & 20.9 & 1.8 & 59 & 68 & 73 & 84 & 96 & 107 & 126 & 139 & 145 \\
\hline 14 & 149 & 100.8 & 102.6 & 23.3 & 2.0 & 65 & 67 & 75 & 86 & 101 & 117 & 133 & 142 & 150 \\
\hline 15 & 152 & 100.3 & 100.9 & 24.9 & 2.2 & 60 & 66 & 68 & 84 & 100 & 117 & 135 & 147 & 159 \\
\hline 16 & 123 & 102.6 & 103.6 & 21.5 & 2.1 & 67 & 70 & 77 & 93 & 103 & 117 & 137 & 140 & 151 \\
\hline 17 & 138 & 98.7 & 101.6 & 23.3 & 2.1 & 65 & 70 & 74 & 86 & 99 & 116 & 137 & 143 & 157 \\
\hline 18 & 131 & 105.5 & 106.4 & 24.4 & 2.3 & 64 & 70 & 75 & 89 & 106 & 125 & 140 & 145 & 165 \\
\hline 19 & 126 & 112.7 & 114.2 & 24.1 & 2.3 & 71 & 76 & 84 & 98 & 113 & 131 & 147 & 157 & 169 \\
\hline total & 1,419 & 103.1 & 105.2 & 23.7 & 0.7 & 65 & 70 & 76 & 89 & 103 & 121 & 139 & 148 & 157 \\
\hline Triglyce & e $(\mathrm{mg} / \mathrm{dL})$ & & & & & & & & & & & & & \\
\hline 10 & 124 & 59 & 66.6 & 32.2 & 2.8 & 19 & 29 & 34 & 45 & 59 & 80 & 110 & 142 & 161 \\
\hline 11 & 157 & 64 & 70.7 & 33.2 & 2.7 & 28 & 31 & 37 & 44 & 64 & 86 & 123 & 137 & 160 \\
\hline 12 & 131 & 68 & 70.3 & 28.9 & 2.6 & 29 & 30 & 33 & 49 & 68 & 90 & 126 & 136 & 153 \\
\hline 13 & 163 & 69 & 76.9 & 36.4 & 2.8 & 27 & 30 & 35 & 46 & 69 & 103 & 129 & 147 & 160 \\
\hline 14 & 147 & 67 & 76.9 & 34.8 & 2.8 & 33 & 34 & 41 & 51 & 67 & 96 & 138 & 150 & 167 \\
\hline 15 & 146 & 73 & 79.5 & 36.3 & 2.8 & 29 & 34 & 38 & 53 & 73 & 101 & 143 & 154 & 163 \\
\hline 16 & 120 & 77 & 82.9 & 35.5 & 3.0 & 29 & 36 & 42 & 56 & 77 & 100 & 129 & 162 & 171 \\
\hline 17 & 129 & 71 & 74.6 & 27.8 & 2.6 & 33 & 42 & 46 & 52 & 71 & 97 & 121 & 149 & 163 \\
\hline 18 & 127 & 75 & 82.8 & 32.9 & 2.7 & 39 & 44 & 50 & 55 & 75 & 104 & 131 & 148 & 171 \\
\hline 19 & 116 & 85 & 86.3 & 33.1 & 3.1 & 28 & 39 & 48 & 61 & 85 & 105 & 128 & 149 & 169 \\
\hline total & 1,360 & 71 & 77.6 & 33.8 & 0.9 & 29 & 34 & 39 & 52 & 71 & 98 & 128 & 147 & 164 \\
\hline
\end{tabular}


Table 2. Distribution of serum lipid levels according to the percentile based on age groups in girls

\begin{tabular}{|c|c|c|c|c|c|c|c|c|c|c|c|c|c|c|}
\hline \multirow{2}{*}{ Age } & \multirow{2}{*}{$\begin{array}{l}\text { Unwei- } \\
\text { ghted N }\end{array}$} & \multirow{2}{*}{ Median } & \multirow{2}{*}{ Mean } & \multirow{2}{*}{ SD } & \multirow{2}{*}{ SE } & \multicolumn{9}{|c|}{ Percentile } \\
\hline & & & & & & 2.5 & 5 & 10 & 25 & 50 & 75 & 90 & 95 & 97.5 \\
\hline \multicolumn{15}{|c|}{ Total cholesterol (mg/dL) } \\
\hline 10 & 101 & 173 & 171.0 & 24.7 & 2.5 & 123 & 125 & 140 & 152 & 173 & 190 & 202 & 206 & 219 \\
\hline 11 & 122 & 160 & 162.0 & 25.6 & 2.3 & 118 & 123 & 127 & 142 & 160 & 179 & 195 & 206 & 216 \\
\hline 12 & 125 & 162 & 165.7 & 25.4 & 2.2 & 117 & 125 & 133 & 151 & 162 & 182 & 207 & 210 & 219 \\
\hline 13 & 138 & 161 & 161.7 & 24.8 & 2.2 & 109 & 124 & 130 & 144 & 161 & 176 & 192 & 209 & 213 \\
\hline 14 & 136 & 164 & 163.2 & 25.8 & 2.2 & 117 & 124 & 130 & 144 & 164 & 179 & 199 & 208 & 220 \\
\hline 15 & 129 & 157 & 160.9 & 23.9 & 2.3 & 121 & 125 & 133 & 146 & 157 & 174 & 193 & 205 & 223 \\
\hline 16 & 134 & 165 & 166.9 & 23.2 & 2.0 & 123 & 126 & 140 & 152 & 165 & 183 & 196 & 208 & 214 \\
\hline 17 & 139 & 160 & 160.0 & 24.3 & 2.0 & 109 & 122 & 128 & 142 & 160 & 178 & 191 & 195 & 205 \\
\hline 18 & 105 & 166 & 167.3 & 23.5 & 2.3 & 119 & 129 & 140 & 152 & 166 & 183 & 196 & 213 & 218 \\
\hline 19 & 132 & 168 & 169.2 & 25.7 & 2.1 & 123 & 128 & 134 & 149 & 168 & 188 & 203 & 214 & 227 \\
\hline total & 1,261 & 164 & 164.8 & 24.9 & 0.7 & 120 & 125 & 132 & 148 & 164 & 182 & 198 & 208 & 218 \\
\hline \multicolumn{15}{|c|}{ LDL cholesterol (mg/dL) } \\
\hline 10 & 100 & 98.9 & 98.7 & 21.1 & 2.1 & 60 & 61 & 72 & 82 & 99 & 115 & 129 & 131 & 134 \\
\hline 11 & 121 & 87.5 & 89.5 & 21.9 & 2.0 & 49 & 59 & 66 & 72 & 88 & 103 & 120 & 127 & 130 \\
\hline 12 & 124 & 90.5 & 93.5 & 22.1 & 2.0 & 51 & 56 & 67 & 80 & 91 & 110 & 126 & 134 & 137 \\
\hline 13 & 138 & 91.4 & 91.3 & 21.0 & 1.8 & 48 & 60 & 64 & 75 & 91 & 104 & 119 & 123 & 134 \\
\hline 14 & 136 & 93.5 & 93.3 & 22.9 & 1.9 & 45 & 53 & 64 & 79 & 94 & 109 & 124 & 134 & 138 \\
\hline 15 & 129 & 90.9 & 92.3 & 21.1 & 2.0 & 55 & 60 & 66 & 79 & 91 & 106 & 122 & 131 & 138 \\
\hline 16 & 134 & 96.1 & 97.6 & 20.8 & 1.8 & 60 & 64 & 69 & 83 & 96 & 114 & 124 & 133 & 141 \\
\hline 17 & 139 & 91.5 & 91.1 & 20.6 & 1.7 & 52 & 58 & 65 & 77 & 92 & 109 & 118 & 125 & 129 \\
\hline 18 & 105 & 93.5 & 95.4 & 19.1 & 1.9 & 61 & 66 & 73 & 82 & 94 & 108 & 122 & 131 & 133 \\
\hline 19 & 130 & 91.8 & 95.4 & 21.8 & 1.9 & 59 & 62 & 68 & 82 & 92 & 113 & 126 & 131 & 134 \\
\hline total & 1,256 & 92.2 & 93.8 & 21.4 & 0.6 & 54 & 60 & 67 & 79 & 92 & 108 & 123 & 131 & 135 \\
\hline \multicolumn{15}{|c|}{ HDL cholesterol $(\mathrm{mg} / \mathrm{dL})$} \\
\hline 10 & 100 & 52.4 & 52.9 & 8.9 & 0.9 & 36 & 38 & 41 & 47 & 52 & 58 & 65 & 70 & 72 \\
\hline 11 & 122 & 52.4 & 52.4 & 9.0 & 0.8 & 34 & 39 & 40 & 47 & 52 & 57 & 65 & 68 & 71 \\
\hline 12 & 128 & 53.4 & 53.6 & 9.8 & 0.9 & 36 & 38 & 41 & 47 & 53 & 62 & 66 & 71 & 74 \\
\hline 13 & 140 & 52.5 & 52.5 & 10.2 & 0.9 & 34 & 36 & 38 & 45 & 53 & 59 & 65 & 72 & 75 \\
\hline 14 & 137 & 52.5 & 52.7 & 10.1 & 0.9 & 37 & 37 & 41 & 44 & 53 & 60 & 67 & 73 & 74 \\
\hline 15 & 131 & 52.4 & 52.3 & 9.6 & 0.8 & 36 & 37 & 39 & 45 & 52 & 60 & 65 & 67 & 71 \\
\hline 16 & 138 & 53.5 & 53.8 & 9.2 & 0.8 & 37 & 39 & 42 & 47 & 54 & 59 & 66 & 69 & 74 \\
\hline 17 & 138 & 52.5 & 53.5 & 10.0 & 0.9 & 33 & 38 & 40 & 47 & 53 & 62 & 68 & 70 & 73 \\
\hline 18 & 105 & 53.5 & 55.2 & 10.3 & 1.0 & 37 & 38 & 42 & 47 & 54 & 63 & 70 & 74 & 77 \\
\hline 19 & 131 & 56.4 & 56.8 & 9.7 & 0.8 & 37 & 42 & 44 & 50 & 56 & 64 & 70 & 75 & 76 \\
\hline total & 1,270 & 53.4 & 53.7 & 9.8 & 0.3 & 36 & 38 & 41 & 47 & 53 & 61 & 67 & 71 & 74 \\
\hline \multicolumn{15}{|c|}{ Non-HDL cholesterol (mg/dL) } \\
\hline 10 & 101 & 118.8 & 117.9 & 23.1 & 2.3 & 71 & 77 & 87 & 103 & 119 & 133 & 147 & 153 & 170 \\
\hline 11 & 120 & 106.4 & 108.5 & 24.4 & 2.2 & 66 & 71 & 78 & 91 & 106 & 127 & 144 & 149 & 155 \\
\hline 12 & 124 & 108.6 & 111.5 & 22.5 & 2.0 & 70 & 73 & 84 & 99 & 109 & 129 & 143 & 149 & 156 \\
\hline 13 & 138 & 108.6 & 109.3 & 22.8 & 2.0 & 69 & 74 & 84 & 94 & 109 & 125 & 144 & 151 & 156 \\
\hline 14 & 135 & 110.1 & 109.8 & 23.3 & 2.0 & 63 & 65 & 80 & 94 & 110 & 123 & 141 & 150 & 158 \\
\hline 15 & 129 & 106.8 & 108.3 & 24.0 & 2.3 & 66 & 70 & 80 & 92 & 107 & 124 & 140 & 150 & 165 \\
\hline 16 & 134 & 111.6 & 113.1 & 21.6 & 1.9 & 71 & 76 & 89 & 98 & 112 & 129 & 140 & 148 & 152 \\
\hline 17 & 138 & 103.6 & 105.6 & 21.3 & 1.8 & 58 & 73 & 78 & 92 & 104 & 122 & 132 & 136 & 144 \\
\hline 18 & 105 & 111.7 & 111.8 & 20.8 & 2.1 & 70 & 77 & 86 & 98 & 112 & 125 & 145 & 149 & 152 \\
\hline 19 & 131 & 107.5 & 110.7 & 23.4 & 2.0 & 73 & 76 & 83 & 95 & 108 & 128 & 144 & 146 & 147 \\
\hline total & 1,255 & 108.8 & 110.4 & 22.9 & 0.6 & 68 & 74 & 82 & 95 & 109 & 127 & 141 & 149 & 156 \\
\hline Triglyce & de $(\mathrm{mg} / \mathrm{dL}$ & & & & & & & & & & & & & \\
\hline 10 & 95 & 84 & 85.4 & 35.0 & 3.8 & 31 & 33 & 41 & 56 & 84 & 105 & 133 & 156 & 163 \\
\hline 11 & 115 & 85 & 85.4 & 32.5 & 3.0 & 35 & 38 & 44 & 58 & 85 & 107 & 131 & 145 & 158 \\
\hline 12 & 121 & 76 & 81.0 & 30.9 & 3.0 & 33 & 40 & 45 & 55 & 76 & 97 & 127 & 144 & 158 \\
\hline 13 & 132 & 79 & 82.8 & 32.5 & 2.7 & 34 & 38 & 46 & 58 & 79 & 102 & 131 & 145 & 162 \\
\hline 14 & 128 & 75 & 79.0 & 29.4 & 2.9 & 37 & 39 & 44 & 54 & 75 & 93 & 117 & 136 & 146 \\
\hline 15 & 124 & 71 & 74.7 & 30.2 & 2.8 & 29 & 33 & 39 & 50 & 71 & 93 & 121 & 125 & 134 \\
\hline 16 & 136 & 73 & 77.5 & 30.7 & 2.7 & 29 & 34 & 40 & 55 & 73 & 103 & 121 & 133 & 137 \\
\hline 17 & 136 & 67 & 70.1 & 26.6 & 2.3 & 32 & 34 & 40 & 49 & 67 & 86 & 108 & 117 & 138 \\
\hline 18 & 104 & 72 & 80.5 & 32.1 & 3.1 & 32 & 38 & 46 & 57 & 72 & 98 & 134 & 147 & 158 \\
\hline 19 & 128 & 69 & 75.9 & 29.1 & 2.7 & 37 & 39 & 44 & 56 & 69 & 88 & 116 & 142 & 150 \\
\hline total & 1,219 & 73 & 78.5 & 31.0 & 0.9 & 33 & 37 & 42 & 54 & 73 & 97 & 123 & 139 & 150 \\
\hline
\end{tabular}




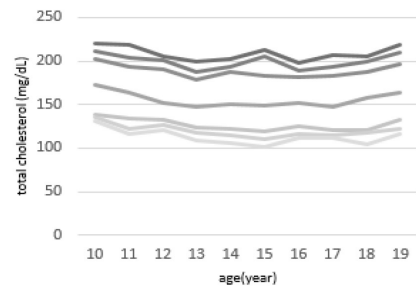

(A)

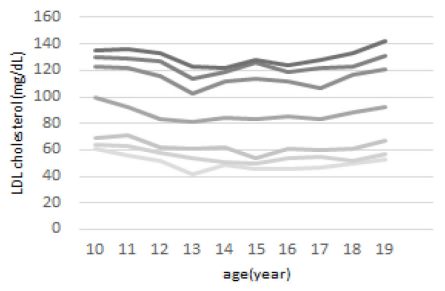

(C)

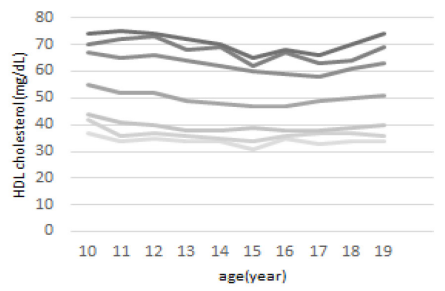

(E)

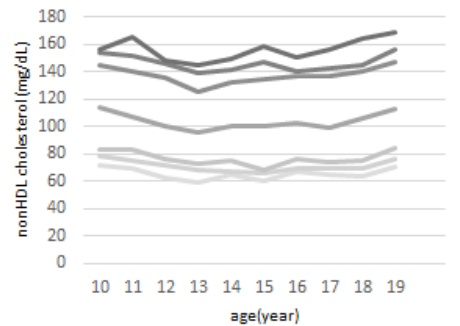

(G)

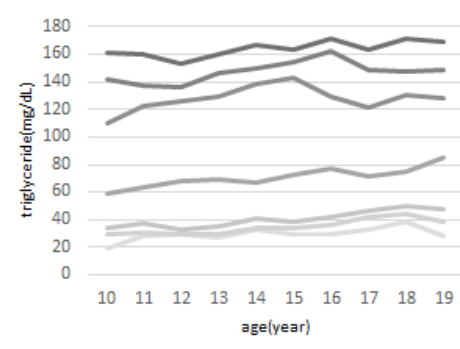

(I)

(J)

(B)

(D)
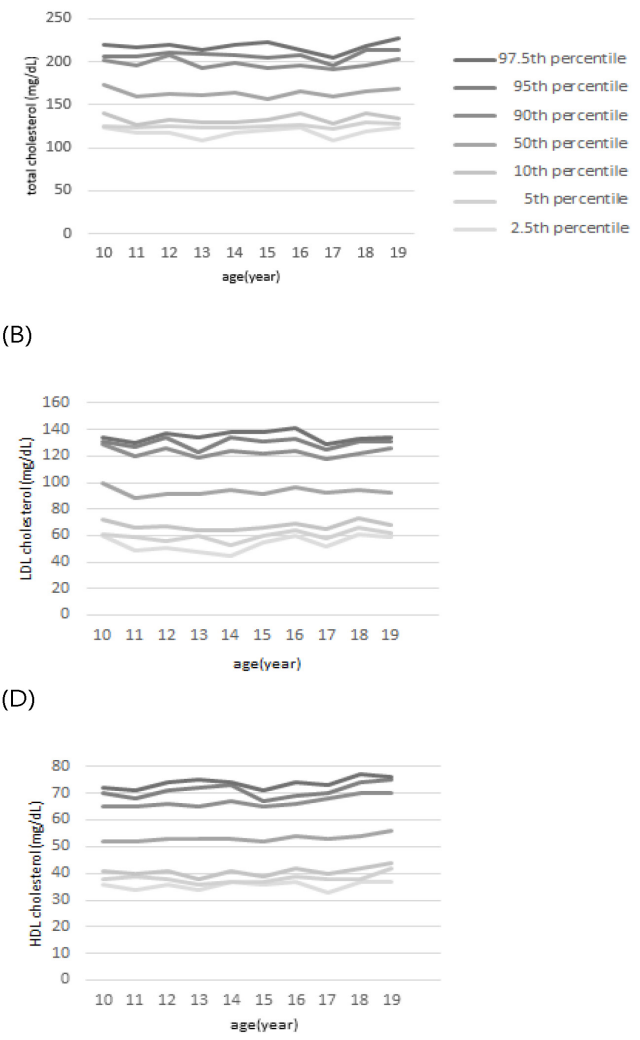

(F)

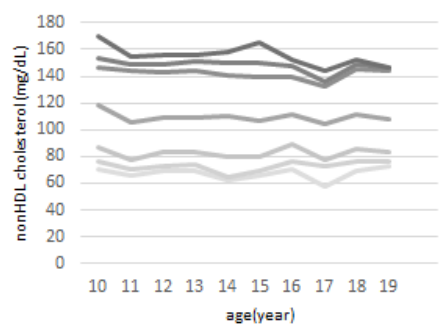

(H)

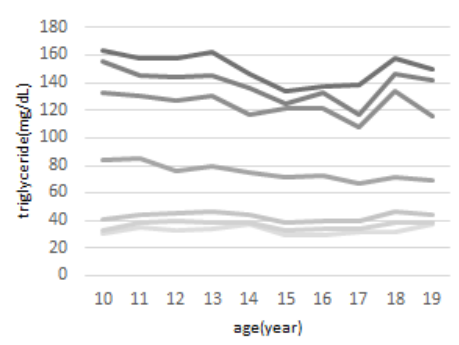

Figure 1. Percentile curves for concentrations of fasting blood lipid. The $2.5^{\text {th }}, 5^{\text {th }}, 10^{\text {th }}, 50^{\text {th }}, 90^{\text {th }}, 95^{\text {th, }} 97.5^{\text {th }}$ percentile curves for total cholesterol in boys (A) and girls (B); for LDL cholesterol in boys (C) and girls (D); for HDL cholesterol in boys (E) and girls (F); for nonHDL cholesterol in boys $(\mathrm{G})$ and girls $(\mathrm{H})$; for triglyceride in boys (I) and girls (J), respectively.
아의 평균 농도는 $53.7 \mathrm{mg} / \mathrm{dL}$ 로 남아의 평균치가 여아보다 더 낮았다. 연령에 따른 농도 비교에서 10세 남아의 평균은 55.7 $\mathrm{mg} / \mathrm{dL}$ 로 가장 높다가 15 17세에 가장 낮아진 후 다시 증가하 였고, 여아의 경우 $10 \sim 15$ 세에 걸쳐 비슷한 분포를 보이다가 점
점 상승하여 19 세에 평균 $56.8 \mathrm{mg} / \mathrm{dL}$ 로 가장 높은 경향을 보였 다. 5 백분위수, 10 백분위수에 해당하는 농도는 각각 남아 36 $\mathrm{mg} / \mathrm{dL}, 39 \mathrm{mg} / \mathrm{dL}$, 여아 $38 \mathrm{mg} / \mathrm{dL}, 41 \mathrm{mg} / \mathrm{dL}$ 였다(Tables 1 , 2) (Figure 1E, 1F). 


\section{4. 공복 non-HDL 콜레스테롤 평균 농도}

Non-HDL 콜레스테롤의 경우 남아의 평균 농도는 105.2 $\mathrm{mg} / \mathrm{dL}$, 여아의 평균 농도는 $110.4 \mathrm{mg} / \mathrm{dL}$ 로 여아의 평균치가 남아보다 더 높았다. 연령에 따른 농도 비교에서 10세 남아의 평 균은 $113.4 \mathrm{mg} / \mathrm{dL}$ 로 높은 상태에서 12 17세에 다소 낮아진 후 유지하다가 다시 증가하여 19세에 평균 $114.2 \mathrm{mg} / \mathrm{dL}$ 로 가 장 높게 나타났다. 여아의 경우 10 세에서 $117.9 \mathrm{mg} / \mathrm{dL}$ 로 가장 높았으며 연령이 증가함에 따라 전반적으로 비슷한 분포를 보 이다가 점점 감소하는 경향을 보였다. 95백분위수에 해당하는 평균 non-HDL 콜레스테롤 농도는 남아 $148 \mathrm{mg} / \mathrm{dL}$, 여아 149 $\mathrm{mg} / \mathrm{dL}$ 였다(Tables 1, 2) (Figure 1G, 1H).

\section{5. 공복 중성지방 평균 농도}

중성지방의 경우 남아의 평균 농도는 $77.6 \mathrm{mg} / \mathrm{dL}$, 여아의 평 균 농도는 $78.5 \mathrm{mg} / \mathrm{dL}$ 로 여아의 평균치가 남아보다 더 높았다. 연령에 따른 농도 비교에서 10세 남아의 평균은 $66.6 \mathrm{mg} / \mathrm{dL}$ 로 가장 낮은 상태에서 연령이 증가함에 따라 증가하여 19세에 평 균 $86.3 \mathrm{mg} / \mathrm{dL}$ 로 가장 높게 나타났다. 여아의 경우 10 세에서 $85.4 \mathrm{mg} / \mathrm{dL}$ 로 가장 높았으며 17 세에 $70.1 \mathrm{mg} / \mathrm{dL}$ 로 가장 낮게 나타났고 연령이 증가함에 따라 전반적으로 점점 감소하는 경 향을 보였다. 95백분위수에 해당하는 농도는 남아 $147 \mathrm{mg} / \mathrm{dL}$, 여아 $139 \mathrm{mg} / \mathrm{dL}$ 였다(Tables 1, 2) (Fig 1I, 1J).

\section{고 찰}

이상지질혈증은 대부분 총콜레스테롤 증가, $\mathrm{LDL}$ 콜레스테 롤 증가, $\mathrm{HDL}$ 콜레스테롤 감소, 중성지방이 증가된 결과로 나타 난다. 소아청소년에서 진단의 기준은 미국콜레스테롤 교육 프 로그램(National Cholesterol Education Program, NCEP)에 서 제시한 고콜레스테롤혈증의 경우 $200 \mathrm{mg} / \mathrm{dL}$ 이상, 고LDL콜레스테롤혈증의 경우 $130 \mathrm{mg} / \mathrm{dL}$ 이상으로 간주하며 이는 지 질 측정치 분포에서 95백분위수 이상에 해당하는 값으로 설정 되었다[12]. 이와 함께 미국 국민건강영양조사 자료를 바탕으 로 심혈관질환 위험과 관련 있는 소아청소년의 참고치는 $\mathrm{HDL}$ 콜레스테롤 $<40 \sim 45 \mathrm{mg} / \mathrm{dL}$, 소아의 중성지방 $>130 \mathrm{mg} / \mathrm{dL}$ $(1.47 \mathrm{mmol} / \mathrm{L})$, 청소년의 중성지방 $>150 \mathrm{mg} / \mathrm{dL}(1.7$ $\mathrm{mmol} / \mathrm{L})$ 의 기준을 제시하였다[13, 14]. 국내에서 적용되고 있 는 기준 중에 하나인 지질동맥경화학회의 소아청소년의 기준은 미국소아과학회 기준과 동일한데, 실제 소아청소년의 혈중 지 질 농도의 분포를 통해 이에 대한 타당성의 여부를 살펴보았다.
본 연구에서 총 콜레스테롤, $\mathrm{LDL}$ 콜레스테롤, $\mathrm{HDL}$ 콜레스테 롤, non-HDL 콜레스테롤 농도는 남아보다 여아에서 더 높았 고, 이는 소아청소년 대상의 여러 연구에서 비슷한 양상이었다 [15-17]. 2007 2013년 한국 소아 청소년 대상의 연구에서도 모든 지질 지표의 평균은 여아에서 더 높았으며, 중성지방의 경 우 남아는 연령이 증가함에 따라 평균 농도도 증가하고, 여아의 경우 감소하는 경향도 동일하였다[15]. 8세에서 18세의 소아청 소년을 대상으로 2006년에서 2013년까지 행해진 네덜란드 라 이프라인 코호트 연구에서도 콜레스테롤, HDL 콜레스테롤, $\mathrm{LDL}$ 콜레스테롤, 중성지방의 경우 모두 남아 보다 여아에서 평 균농도가 더 높게 나타났고[16], 6세 19세 대상으로 한 2010 2015년의 북유럽 연구에서도 비슷한 양상을 보였다[17]. 이는 성호르몬과의 연관성으로 제시하고 있는데, 터키 어린이와 청 소년에서는 낮은 HDL-콜레스테롤 수치의 중요한 예측 인자라 고 보고하였다[18, 19]. 특히 지질 혈중 지표 중 공복 검사를 필 요로 하지 않고, 중성지방 농도에 영향을 받지 않으면서 LDL 콜 레스테롤을 포함한 동맥경화성 지단백을 포함하며 계산이 간편 한 non-HDL 콜레스테롤의 측정에 대한 관심이 커지고 있는데 [20], 본 연구에서 non-HDL 콜레스테롤 또한 남아보다 여아에 서 평균 농도가 높았고, 여아의 경우 연령이 증가할수록 감소하 는 경향도 터키의 소아청소년과 동일한 양상이었다[21]. 일본 의 경우에도 평균 농도의 분포는 유사하였고 95 백분위 수가 약 $150 \mathrm{mg} / \mathrm{dL}$ 이었으며 연령과 성별에 따라 다르므로 참고 범위 의 관리가 죽상동맥경화증 예방과 관련하여 유용한 도구가 될 수 있다고 하였다[22].

총 콜레스테롤 농도의 95 백분위수에 해당하는 값은 남아의 경우 $200 \mathrm{mg} / \mathrm{dL}$ 로 95백분위수와 일치하는 수준이었고, 여아 의 경우 $208 \mathrm{mg} / \mathrm{dL}$ 로 나타나 고콜레스테롤혈증 진단기준은 남 녀 모두 90 95백분위수 사이에 해당하였다. 2007년 2010 년 자료를 대상으로 한 소아청소년에서 90백분위수는 남아의 경우 $192 \mathrm{mg} / \mathrm{dL}$, 여아의 경우 $195 \mathrm{mg} / \mathrm{dL}$ 였으나[23], 2013 2016년에 해당하는 본 연구에서 남아의 경우 $189 \mathrm{mg} / \mathrm{dL}$ 로 낮 아진 반면, 여아의 경우 $198 \mathrm{mg} / \mathrm{dL}$ 로 높아져 여아의 콜레스테 롤 농도 상승을 볼 수 있었다. 본 연구 결과 $\mathrm{LDL}$ 콜레스테롤, non-HDL 콜레스테롤, 중성지방의 95백분위수는 남아의 경우 각각 $123,148,147 \mathrm{mg} / \mathrm{dL}$ 였으며, 여아의 경우 각각 131,149 , $139 \mathrm{mg} / \mathrm{dL}$ 였다. 현재 국내에서 적용하고 있는 기준인 LDL 콜 레스테롤 $130 \mathrm{mg} / \mathrm{dL}$ 는 여아에서는 적절하다고 여겨지나, 남 아에서는 95 백분위수가 $123 \mathrm{mg} / \mathrm{dL}$ 으로 나타났고, $130 \mathrm{mg} / \mathrm{dL}$ 에 해당하는 기준은 남아 19 세의 95 백분위수에 해당하는 높은 수준으로 나타났다. Non-HDL 콜레스테롤의 경우 남아와 여아 
모두 90 95백분위수 범위 내의 적절한 수준에서 관찰되었다. 중성지방의 경우 소아에서 청소년기에 이르는 130 또는 150 $\mathrm{mg} / \mathrm{dL}$ 의 기준은 한국 남자 청소년에서는 90 95백분위수에 해당하였으나, 연령이 증가함에 따라 농도의 감소를 보였던 여 자 청소년의 경우에는 다소 높은 기준이라 판단되었다. $\mathrm{HDL}$ 콜 레스테롤의 5 10백분위수는 남아의 경우 $36 \sim 39 \mathrm{mg} / \mathrm{dL}$, 여 아의 경우 $38 \sim 41 \mathrm{mg} / \mathrm{dL}$ 였는데 $<40 \mathrm{mg} / \mathrm{dL}$ 에 해당하는 기준 은 10백분위수에 해당하며 2007년 2010년 대상의 연구 결과 와 거의 유사하였다[23].

본 연구를 통해 소아청소년의 성별과 연령에 따른 공복 혈청 지질 농도의 분포를 살펴보면서 백분위수 값과 이상지질혈증 진단기준을 비교해봄으로써 참고범위 및 진단기준의 타당성을 검토해보고자 하였다. 현재까지 이상지질혈증에 대한 연구는 국가별로 많이 진행되어 왔고 생애 주기 중에서 소아청소년기 의 공통된 특성이 상당부분 나타났지만, 성별과 연령에 따른 특 성을 고려하지 않은 기준을 사용하면 조기 발견을 놓치거나 과 잉 진료를 하게 되는 문제가 생길 수 있다. 미국의 경우 건강한 체중 어린이를 대상으로 연령에 따른 인구 기준에 맞는 백분위 수를 이용하여 콜레스테롤 기준 곡선을 만들려는 시도도 행해 졌는데[24], 우리나라 청소년의 특성에 맞는 기준 정립이 필요 하다고 여겨진다. 4 개년도에 걸친 연구자료를 이용하였음에도 불구하고 소아청소년의 성별과 각 연령군에서 참고범위를 설정 하기에는 대상자 수가 작은 연령군이 있어 참고범위를 제시하 기에는 무리가 있었고, 그로 인해 성별과 연령에 따른 차이를 검 증하지는 못해 연구의 제한점으로 남는다. 향후 연구대상자 및 자료를 보완하여 성별과 연령에 따른 특성을 반영함으로써 우 리 실정에 좀 더 적합한 기준을 마련하면 이상지질혈증 조기 진 단을 위한 예방 및 관리에 도움이 될 것이다.

\section{요 약}

소아청소년기의 이상지질혈증 유병율이 증가함에 따라 이에 대한 조기발견과 관리에 대한 중요성이 커지고 있다. 본 연구는 소아청소년의 성별과 연령에 따른 공복 혈청 지질 농도의 분포 를 살펴보고, 참고 범위 설정을 위한 백분위수 값을 검토하여 이 상지질혈증 진단기준과 비교해 봄으로써 참고범위의 타당성을 검증하고자 하였다. 2013년부터 2016년까지 총 4년에 걸친 국 민건강영양조사 자료에서 10세 이상 20세 미만 연령의 소아청 소년 총 2,711 명(남자 1,436 명, 여자 1,275 명)의 데이터를 대 상으로 하였다. 총콜레스테롤, $\mathrm{LDL}$ 콜레스테롤, $\mathrm{HDL}$ 콜레스테 롤, non-HDL 콜레스테롤, 중성지방의 평균 공복 혈중 농도는
모두 남아보다 여아에서 더 높았다. 총 콜레스테롤 농도의 95백 분위수에 해당하는 값은 남아의 경우 $200 \mathrm{mg} / \mathrm{dL}$ 로 95백분위 수와 일치하는 수준이었고, 여아의 경우 $208 \mathrm{mg} / \mathrm{dL}$ 로 나타나 90 95백분위수 사이에 해당하였다. LDL 콜레스테롤, non-HDL 콜레스테롤, 중성지방의 95 백분위수는 남아의 경우 각각 123 , $148,147 \mathrm{mg} / \mathrm{dL}$ 였으며, 여아의 경우 각각 $131,149,139$ $\mathrm{mg} / \mathrm{dL}$ 였다. 대부분의 지표는 90 95백분위수 범위 내의 적절 한 수준으로 나타났다. 반면에 LDL 콜레스테롤 $130 \mathrm{mg} / \mathrm{dL}$ 기 준은 남아에서, 중성지방의 기준은 여아에서 다소 높은 수준이 라 판단되었다. 향후 연구대상자 및 자료를 보완하여 우리 실정 에 좀 더 적합한 기준 정립이 필요하다.

\section{Acknowledgements: None \\ Conflict of interest: None}

\section{REFERENCES}

1. Statistics Korea. Online publications of Korea Statistical Yearbooks are provided on the KOSIS [Internet]. Seoul: Statistics Korea; 2016 [cited 2018 June 10]. Available from: http://kosis.kr/publication/publicationThema.do.

2. Health Insurance Review \& Assessment Service. 4 severe disease statistics [Internet]. Seoul: Health Insurance Review \& Assessment Service; 2017 [cited 2018 June 10]. Available from: http://opendata.hira.or.kr/op/opc/olapOecdInfo.do.

3. Berenson GS, Srinivasan SR, Bao W, Newman III WP, Tracy RE, Wattigney WA. Association between multiple cardiovascular risk factors and atherosclerosis in children and young adults. The Bogalusa Heart Study. N Engl J Med, 1998;338:1650-1656.

4. Daniels SR, Greer FR. Lipid screening and cardiovascular health in childhood. Pediatrics. 2008;122:198-208.

5. Fuentes RM, Notkola IL, Shemeikka S, Tuomilehto J, Nissinen A. Tracking of serum total cholesterol during childhood: an 8-year follow-up population-based family study in eastern Finland. Acta Paediatr. 2003;92:420-424.

6. YM Hong. Atherosclerotic cardiovascular disease beginning in childhood. Korean Circ J. 2010;40:1-9.

7. Nguyen DT, Kit BK, Carroll MD. Abnormal cholesterol among children and adolescents in the United States, 2011-2014. NCHS Data Brief. 2015;228:1-8.

8. Freedman DS, Bowman BA, Srinivasan SR. Berenson GS, Otvos JD. Distribution and correlates of high-density lipoprotein subclasses among children and adolescents. Metabolism. 2001;50: 370-376.

9. Srinivasan SR, Myers L, Berenson GS. Distribution and correlates of non-high-density lipoprotein cholesterol in children: the Bogalusa Heart Study. Pediatrics. 2002;110:e29.

10. Jolliffe CJ, Janssen I. Distribution of lipoproteins by age and gender in adolescents. Circulation. 2006;114:1056-1062.

11. Strand MF, Fredriksen PM, Hjelle OP, Lindberg M. Reference in- 
tervals for serum lipids and prevalence of dyslipidemia in 6-12-year-old children: The Health Oriented Pedagogical Project (HOPP). Scand J Public Health. 2018;46(21 suppl): 21-27.

12. National Cholesterol Education Program (NCEP). Highlights for the report of the expert panel on blood cholesterol levels in children and adolescents. Pediatrics. 1992;89:495-501.

13. Kavey RE, Daniels SR, Lauer RM, Atkins DL, Hayman LL, Taubert K. American Heart Associaion guidelines for primary prevention of atherosclerotic cardiovascular disease beginning in childhood. Circulation. 2003;107:1562-1566.

14. Gidding SS, Lichtenstein AH, Faith MS, Karpyn A, Mennella JA, Popkin B, et al. Implementing American Heart Association pediatric and adult nutrition guidelines. A scientific statement from the American Heart Association Nutrition Committee of the council on nutrition, physical activity and metabolism, council on cardiovascular disease in the young, council on arteriosclerosis, thrombosis and vascular biology, council on cardiovascular nursing, council on epidemiology and prevention, and council for high blood pressure research. Circulation. 2009;119:1161-1175.

15. Shim YS, Baek JW, Kang MJ, Oh YJ, Yang S, Hwang IT. Reference values for the triglyceride to high-density lipoprotein cholesterol ratio and non-high-density lipoprotein cholesterol in Korean children and adolescents: The Korean National Health and Nutrition Examination Surveys 2007-2013. J Atheroscler Thromb. 2016;23:1334-1344.

16. Balder JW, Lansberg PJ, Hof MH, Wiegman A, Hutten BA, Kuivenhoven JA. Pediatric lipid reference values in the general population: The Dutch lifelines cohort study. J Clin Lipidol. 2018. https://doi.org/10.1016/j.jacl.2018.05.011. [Epub ahead of print]

17. Nielsen TRH, Lausten-Thomsen U, Fonvig CE, Bøjsøe C, Pedersen L, Bratholm PS, et al. Dyslipidemia and reference values for fasting plasma lipid concentrations in Danish/NorthEuropean White children and adolescents. BMC Pediatr. 2017; $17: 116$.

18. de Oya I, Schoppen S, Lasuncion MA, Lopez-Simon L, Riestra P, de Oya M, et al. Sex hormone-binding globulin levels and metabolic syndrome and its features in adolescents. Pediatric Diabetes. 2010;11:188-194.

19. Agirbasli M, Agaoglu NB, Orak N, Caglioz H, Ocek T, Karabag T, et al. Sex hormones, insulin resistance and high-density lipoprotein cholesterol levels in children. Horm Res Paediatr. 2010;73:166-174.

20. Virani SS. Non-HDL Cholesterol as a metric of good quality of care. Tex Heart Inst J. 2011;38:160-162.

21. Uçar B, Kiliç Z, Dinleyici EC, Colak O, Güneş E. Serum lipid profiles including non-high density lipoprotein cholesterol levels in Turkish school-children. Anadolu Kardiyol Derg. 2007; 7:415-420.

22. Abe Y, Okada T, Sugiura R, Yamauchi K, Murata M. Reference ranges for the non-high-density lipoprotein cholesterol levels in Japanese children and adolescents. J Atheroscler Thromb. 2015;22:669-675.

23. Kim SH, Ahn BC, Joung HJ, Park MJ. Lipid profiles and prevalence of dyslipidemia in Korean adolescents. Endocrinol Metab. 2012;27:208-216.

24. Skinner AC, Steiner MJ, Chung AE, Perrin EM. Cholesterol curves to identify population norms by age and sex in healthy weight children. Clin Pediatr (Phila). 2012;51:233-237. 